УДК: 599.323.4:577:591.16

doi: $10.36359 /$ scivp.2019-20-2.46

\title{
ІНТЕНСИВНІСТЬ ОКИСНИХ ПРОЦЕСІВ У СПЕРМІ КНУРІВ ЗА ДОДАВАННЯ НАНОСУКЦИНАТІВ МЕТАЛІВ У РОЗРІДЖУВАЧ «ЕКОСПЕРМ»
}

\author{
С. Б. Корнят ${ }^{1}$, канд. с.-г. н., с. н. с., \\ I. М. Яремчук ${ }^{1}$, канд. с.-г. наук, \\ О. Б. Андрушко , канд. біол. наук \\ Д. Д. Остапів ${ }^{1}$, д-р с.-г. наук, \\ M. М. Шаран ${ }^{l}, \partial-р$ с.-г. наук, проф.,

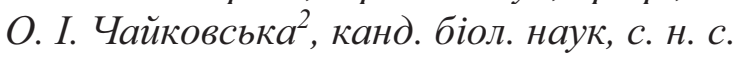 \\ ${ }^{1}$ Інститут біології тварин НААН, \\ вул. В.Стуса 38, м. Львів, 79034, Україна \\ ${ }^{2}$ Державний науково-дослідний контрольний інститут ветеринарних препаратів \\ та кормових добавок, \\ вул. Донецька, 11, м. Львів, 79019, Україна
}

Метою роботи було дослідити вплив комплексів наносукиинатів мангану, міді та цинку в складі середовища «Екосперм» для розрідження еякулятів кнурів на якість спермї̈в протягом зберігання. Встановлено, щз додавання в розріджувач еякулятів кнурів наносукиинатів мікроелементів впливає на інтенсивність окисних процесів у спермі, виживання й активність ензиму-маркера запліднювальної здатності сперміїв сукиинатдегідрогенази. Оптимальною конщентрачією, яка забезпечує нормалізацію окисних прочесів і високе виживання сперміїв у розрідженій спермі кнурів є 0,01 мл/мл середовища $\mathrm{Mn}^{2+}-\left(0,1\right.$ мг/л), $\mathrm{Cu}^{2+}-\left(0,04\right.$ мг/л) $\mathrm{i} \mathrm{Zn}^{2+}-(0,6$ мг/л) наносукцинатів. Збільшення концентрацій наносукцинатів мікроелементів в розріджувачі понад оптимальні величини інгібує дихальну активність сперми та знижує активність сукцинатдегідрогенази статевих клітин.
Ключові
слова:
СПЕРМА,
КНУРI,
СЕРЕДОВИЩЕ,
ВИЖИВАННЯ, НАНОСУКЦИНАТ, МІДЬ, МАНГАН, ЦИНК.

Якість і запліднювальна здатність сперміїв залежить від фізіологічних характеристик еякулятів самців [1]. При цьому, виживання і стійкість статевих клітин до зовнішніх чинників забезпечуються ензимами сперми, які беруть участь у використанні енергетичних субстратів, руйнуванні активних форм Оксигену та знищенні цитотоксичних продуктів обміну. Активність ензимів забезпечується присутністю кофакторів, до яких належать: $\mathrm{Zn}^{2+}, \mathrm{Cu}^{2+} \mathrm{i}$ $\mathrm{Mn}^{2+}[2,3]$. Зокрема, $\mathrm{Zn}^{2+}$ входить в активні центри численних ензимів гліколізу й пентозофосфатного шляху окиснення глюкози, $\mathrm{Cu}^{2+}$ забезпечує активність ензимів дихального ланцюга і протеїназ, а $\mathrm{Mn}^{2+}$ - ензимів циклу Кребса. Крім того, вказані мікроелементи входять в активні центри першої ланки ензиматичного антиоксидантного захисту супероксиддисмутази (СОД). Відомо, що СОД існує в сперміях у трьох генетично зумовлених ізоформах, які містять у каталітичному центрі йони: $\mathrm{Mn}^{2+}-$ мітохондріальній; $\mathrm{Zn}^{2+}$ i $\mathrm{Cu}^{2+}$ цитоплазматичній і екзоцелюлярній. Доведено, що від активності вказаного ензиму та співвідношення його ізозимів, вмісту Міді залежить виживання і, відповідно, запліднювальна здатність статевих клітин самців ссавців.

Оскільки, за розрідження еякулятів знижуються концентрації вказаних йонів, одним зі шляхів нормалізації активності ензимів, які забезпечують використання субстратів i 
антиоксидантний захист та, відповідно, фізіологічні якості й запліднювальну здатність сперміїв $\epsilon$ додавання кофакторів $\left(\mathrm{Cu}^{2+}, \mathrm{Zn}^{2+}\right.$ та $\left.\mathrm{Mn}^{2+}\right)$. Однак, використання вказаних мікроелементів у вигляді солей в складі розріджувачів не ефективне. Це зумовлено нетривалим контактом їх зі статевими клітинами після розрідження, низькою проникливістю через мембрани та здатністю включатись в метаболізм, присутністю інших складових сполук солей. Покращити і забезпечити ефективну дію мікроелементів, нормалізуючи метаболізм сперміїв, можна шляхом їх використання у поєднанні з органічними кислотами, зокрема, у вигляді наносукцинатів [4].

Метою роботи було вивчення впливу мікроелементів у формі наносукцинату в складі середовища розрідження еякулятів кнурів «Екосперм» на інтенсивність окисних процесів у спермі та фізіологічні характеристики сперміїв.

Матеріали і методи. Дослідження проведені в Інституті біології тварин НААН та ЛНВЦ «Західплемресурси». Сперму отримували мануальним способом 3 режимом використання кнурів два рази на тиждень. Для досліджень відібрано еякуляти, об' $є м о м ~ 160 \pm 15$

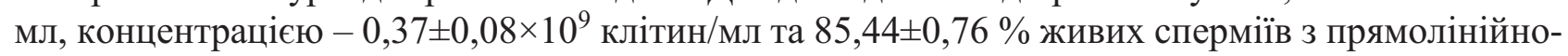
поступальним рухом (табл. 1). Сперму, розріджену середовищем «Екосперм», ділили на частини: контрольну - без додавання та дослідні - $з$ додаванням по 0,001, 0,01 і 0,1 мл $\mathrm{Zn}^{2+}$-, $\mathrm{Cu}^{2+}-$ та $\mathrm{Mn}^{2+}$ - наносукцинатів у мл розріджених еякулятів. Таким чином в досліджуваних зразках було, відповідно: $\mathrm{Zn}^{2+}-0,06,0,6$ і 3,0; $\mathrm{Cu}^{2+}-0,004,0,04$ та 0,4; $\mathrm{Mn}^{2+}-0,01,0,1$ і 1,0 мг/л. Синтез сполук металів з сукцинатом здійснено з використанням аквананотехнології Українським державним науково-дослідним інститутом нанотехнологій і ресурсозбереження (м. Київ).

Таблиия 1

Фізіологічна характеристика якості еякулятів кнурів

\begin{tabular}{|l|c|c|c|c|}
\hline Якість еякулятів & $\mathrm{n}$ & $\mathrm{M} \pm \mathrm{M}$ & Sigma & $\mathrm{Cv}$ \\
\hline Об'єм еякуляту, мл & 10 & $160 \pm 15,0$ & 47,7 & 29,81 \\
\hline Концентрація сперміїв, 109/мл & 8 & $0,37 \pm 0,08$ & 0,23 & 68,45 \\
\hline Кількість живих сперміїв, \% & 9 & $85,4 \pm 0,76$ & 2,27 & 2,65 \\
\hline
\end{tabular}

Визначали: виживання сперміїв (год) за температури $2-4{ }^{\circ} \mathrm{C}$ до припинення поступального руху, дихальну активність - полярографічно (нг-атом O/хв $\times 0,1$ мл сперми) за температури $38,5{ }^{\circ} \mathrm{C}$ і відновну здатність - потенціометрично ( $\mathrm{mV} / \mathrm{xв} \times 0,1$ мл сперми), активність сукцинатдегідрогенази (СДГ; од/год×0,1 мл сперми). Інтенсивність дихання $\mathrm{i}$ відновну здатність сперми досліджували у фосфатно-сольовому буфері ( $\mathrm{NaCl}-0,8$ г, $\mathrm{KCl}-$ 0,02 г, $\mathrm{Na}_{2} \mathrm{HPO}_{4}-0,11$ г, $\mathrm{KH}_{2} \mathrm{PO}_{4}-0,02$ г, $\mathrm{MgCl}_{2}-0,01$ г, $\mathrm{H}_{2} \mathrm{O}$ до 100 мл). Статистичний аналіз цифрового матеріалу проведено за М. О. Плохінським [5-7].

Результати й обговорення. Дихальна активність сперми кнурів у контролі - 1,27士0,04 нг-атом О/ хв $\times 0,1$ мл сперми, а за додавання мікроелементів у вигляді наносполуки 3 сукцинатом змінюється неоднозначно, і залежить від дози в розріджувачі й ролі окремого мікроелемента в обмінних процесах сперміїв. Так, додавання 0,001 мл/мл $\mathrm{Zn}^{2+}$-сукцинату в розріджену сперму майже не змінює дихальну активність, яка становить 1,43 нг-атом O/ хв $\times 0,1$ мл сперми (табл. 2). Збільшення до 0,01 і 0,1 мл/мл $\mathrm{Zn}^{2+}$-сукцинату в розріджених еякулятах, відповідно, на 24,4 і 31,5 \% знижує інтенсивність дихання. Різниця між контролем i максимальною дозою $\mathrm{Zn}^{2+}$-сукцинату статистично вірогідна ( $<<0,05 ; 31,5$ \%). Сила впливу зростаючого вмісту комплексної сполуки в розрідженій спермі на дихальну активність середньої сили $(\eta=0,410)$.

Додавання $\mathrm{Cu}^{2+}$ i $\mathrm{Mn}^{2+}$-сукцинату в розріджені еякуляти кнурів проявляє подібну залежність. За 0,1 мл/мл $\mathrm{Mn}^{2+}$-сукцинату і 0,1 мл/мл $\mathrm{Cu}^{2+}$-сукцинату дихальна активність сперми 0,91 i 0,57 нг-атом О/хв $\times 0,1$ мл сперми відповідно. За менших доз вказаних наносукцинатів мікроелементів інгібування дихальної активності характеризується 
проміжними величинами значень. Сила впливу зростаючого вмісту $\mathrm{Cu}^{2+}$ - і $\mathrm{Mn}^{2+}$-сукцинатів в розрідженій спермі кнурів на дихальну активність сперміїв середньої сили (відповідно, $\eta=$ $0,628$ i 0,539$)$.

Інтенсивність окисних процесів у спермі кнурів за додавання наносукцинатів металів у розріджувач «Екосперм»

\begin{tabular}{|c|c|c|c|c|c|}
\hline \multirow[t]{2}{*}{ Наносукцинати: } & \multirow{2}{*}{$\begin{array}{c}\text { Кількість } \\
\text { добавки, мл/мл }\end{array}$} & \multicolumn{2}{|c|}{$\begin{array}{c}\text { Дихальна активність, нг-атом } \\
\text { O/хв } \times 0,1 \text { мл сперми }\end{array}$} & \multicolumn{2}{|c|}{$\begin{array}{l}\text { Відновна здатність, } \\
\mathrm{mV} / \mathrm{xв} \times 0,1 \text { мл сперми }\end{array}$} \\
\hline & & $\mathrm{n}$ & $\mathrm{M} \pm \mathrm{m}$ & $\mathrm{n}$ & $\mathrm{M} \pm \mathrm{m}$ \\
\hline \multirow{4}{*}{$\mathrm{Zn}^{2+}$} & 0,1 & 7 & $0,87 \pm 0,16^{*}$ & 7 & $0,05 \pm 0,01$ \\
\hline & 0,01 & 7 & $0,96 \pm 0,17$ & 7 & $0,05 \pm 0,01$ \\
\hline & 0,001 & 8 & $1,43 \pm 0,22$ & 8 & $0,04 \pm 0,01$ \\
\hline & $\eta$ & - & 0,410 & - & 0,173 \\
\hline \multirow{4}{*}{$\mathrm{Mn}^{2+}$} & 0,1 & 7 & $0,91 \pm 0,09^{*}$ & 7 & $0,03 \pm 0,01$ \\
\hline & 0,01 & 7 & $0,93 \pm 0,14^{*}$ & 7 & $0,02 \pm 0,01$ \\
\hline & 0,001 & 8 & $0,89 \pm 0,07^{* * *}$ & 8 & $0,03 \pm 0,01$ \\
\hline & $\eta$ & - & 0,539 & - & 0,219 \\
\hline \multirow{4}{*}{$\mathrm{Cu}^{2+}$} & 0,1 & 7 & $0,57 \pm 0,13^{* * *}$ & 7 & $0,11 \pm 0,03$ \\
\hline & 0,01 & 7 & $0,86 \pm 0,13^{* *}$ & 7 & $0,10 \pm 0,02$ \\
\hline & 0,001 & 8 & $1,23 \pm 0,12$ & 8 & $0,14 \pm 0,04$ \\
\hline & $\eta$ & - & 0,628 & - & 0,084 \\
\hline Контроль & - & 42 & $1,27 \pm 0,04$ & 34 & $0,10 \pm 0,03$ \\
\hline
\end{tabular}

Примітка: в цій та наступній таблиці статистично вірогідна різниця між дослідними зразками порівняно до контролю: * ${ }^{*} \mathrm{p}<0,05, * *-\mathrm{p}<0,01, * * *-\mathrm{p}<0,001$.

Одночасно, за додавання пропорційно наростаючих доз наносукцинатів цинку та мангану в розрідженій спермі знижується відновна здатність на $0,05-0,08 \mathrm{mV} / \mathrm{xв} \times 0,1 \mathrm{мл}$ сперми. За додавання аналогічних доз наносукцинатів міді в розрідженій спермі відновна здатність сперми становить $0,11-0,14 \mathrm{mV} / \mathrm{xв} \times 0,1$ мл сперми і знаходиться в межах контролю. Залежність відновної здатності від збільшення дози наносукцинатів мікроелементів у розрідженій спермі слабкої сили $(\eta=0,084-0,219)$.

Активність СДГ за додавання 0,001 мл/мл $\mathrm{Zn}^{2+}$-сукцинату в розріджені еякуляти знижується на 20 од/год $\times 0,1$ мл сперми $(42,2 \%$; p $<0,05)$, а за вищого вмісту на 50,0-52,6 \%, порівняно 3 контролем. Аналогічні зміни встановлені за додавання $\mathrm{Mn}^{2+}$-сукцинату, однак різниця між контролем та максимальним вмістом (0,1 мл/мл) становить 36,5 \% (p > 0,05; табл. $3)$.

Таблиия 3

Фізіологічні характеристики сперміїв за додавання наносукцинатів металів у розріджувач еякулятів кнурів

\begin{tabular}{|c|c|c|c|c|c|}
\hline \multirow{2}{*}{ Наносукцинати: } & \multirow{2}{*}{$\begin{array}{c}\text { Кількість } \\
\text { добавки, мг/л }\end{array}$} & \multicolumn{2}{|c|}{ СДГ, од/год×0,1 мл сперми } & \multicolumn{2}{|c|}{ Виживання, год } \\
\cline { 2 - 6 } & 0,1 & $\mathrm{n}$ & $\mathrm{M} \pm \mathrm{m}$ & $\mathrm{n}$ & $\mathrm{M} \pm \mathrm{m}$ \\
\hline \multirow{4}{*}{$\mathrm{Zn}^{2+}$} & 0,01 & 8 & $22,5 \pm 8,00$ & 10 & $93,6 \pm 19,03$ \\
\cline { 2 - 6 } & 0,001 & 14 & $23,7 \pm 5,13^{*}$ & 10 & $96,0 \pm 16,63$ \\
\cline { 2 - 6 } & $\mathrm{H}$ & - & 0,513 & 16 & $82,5 \pm 12,99$ \\
\hline \multirow{3}{*}{$\mathrm{Mn}^{2+}$} & 0,1 & 8 & $30,2 \pm 8,06$ & 10 & $69,6 \pm 10,97$ \\
\cline { 2 - 6 } & 0,01 & 8 & $34,4 \pm 7,78$ & 10 & $76,8 \pm 10,63$ \\
\cline { 2 - 6 } & 0,001 & 14 & $43,4 \pm 7,18$ & 16 & $72,0 \pm 8,76$ \\
\cline { 2 - 6 } & $\eta$ & - & 0,281 & - & 86,130 \\
\hline \multirow{3}{*}{$\mathrm{Cu}^{2+}$} & 0,1 & 8 & $14,4 \pm 2,72^{* * *}$ & 10 & $91,2 \pm 15,25$ \\
\cline { 2 - 6 } & 0,01 & 14 & $24,6 \pm 3,33^{* * *}$ & 10 & $66,0 \pm 9,19$ \\
\cline { 2 - 6 } & 0,001 & - & 0,666 & - & 0,249 \\
\hline
\end{tabular}


$\mathrm{Cu}^{2+}$-сукцинат проявляє токсичний вплив на СДГ, оскільки за пропорційного підвищення дози вказаної сполуки величина активності ензиму поступово знижується: за 0,001 мл/мл - на 48,1 \% (p <0,001), за 0,01 мл/мл - на 64,5\% $\%$ p <0,001) і за 0,1 мл/мл - на $69,7 \%(\mathrm{p}<0,001)$.

Виживання сперміїв у середовищі розрідження еякулятів кнурів «Екосперм» за низьких

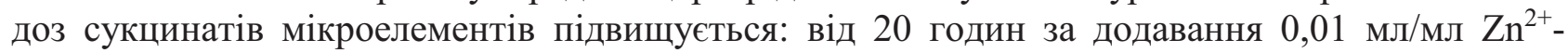
сукцинату в розріджені еякуляти до 6 годин за 0,01 мл/мл $\mathrm{Cu}^{2+}$-сукцинату. За додавання 0,01 мл/мл сукцинату всіх трьох досліджуваних мікроелементів (цинку, мангану і міді) у розріджену сперму виживання сперміїв кнура на 33,2, 9,2 і 28,4 години вище, порівняно 3 контролем. Збільшення вмісту $\mathrm{Zn}^{2+}-, \mathrm{Mn}^{2+}$ i $\mathrm{Cu}^{2+}$-сукцинатів до максимальних доз (0,1 мл/мл) зумовлює тенденцію до зниження виживання сперміїв.

Отже, додавання в розріджувач еякулятів кнурів наносукцинатів мікроелементів впливає на інтенсивність окисних процесів у спермі, виживання й активність ензиму-маркера запліднювальної здатності сперміїв. Оптимальними дозами, які забезпечують нормалізацію окисних процесів і високе виживання сперміїв у розрідженій спермі кнурів є: 0,001 та 0,01 мл/мл наносукцинатів, відповідно, у концентраціях 0,01 і 0,1 мг/л $\mathrm{Mn}^{2+}-, 0,004$ і 0,04 мг/л $\mathrm{Cu}^{2+}$ - та 0,06 і 0,6 мг/л $\mathrm{Zn}^{2+}$. Збільшення концентрацій наносукцинатів мікроелементів в розріджувачі більше оптимальних величин інгібує дихальну активність сперми та знижує активність сукцинатдегідрогенази.

\title{
В И С Н О В К И
}

1. Дихальна активність сперми кнурів за додавання мікроелементів у вигляді наносполуки з сукцинатом змінюється неоднозначно, і залежить від дози в розріджувачі й ролі окремого мікроелемента в обмінних процесах сперміїв.

2. Різниця між контролем і максимальною дозою $\mathrm{Zn}^{2+}$-наносукцинату - 31,5 \%, а сила впливу зростаючого вмісту комплексної сполуки в розрідженій спермі на дихальну активність середньої сили $(\eta=0,410)$.

3. Сила впливу зростаючого вмісту $\mathrm{Cu}^{2+}$ - і $\mathrm{Mn}^{2+}$-сукцинатів в розрідженій спермі кнурів на дихальну активність сперміїв середньої сили (відповідно, $\eta=0,628$ і 0,539).

4. За додавання 0,01 мл/мл наносукцинатів $\mathrm{Zn}^{2+}-(0,6 \mathrm{мг} / л), \mathrm{Mn}^{2+}-(0,1 \mathrm{мг} / л)$ i $\mathrm{Cu}^{2+}-(0,04$ мг/л) у розрідженій спермі встановлено найбільшу тривалість виживання сперміїв кнура, порівняно з контролем.

Перспективи досліджень. Вивчити вплив наносукцинатів мікроелементів на біохімічні та фізіологічні показники сперміїв розріджених еякулятів кнурів.

\section{THE INTENSITY OF THE OXIDATION PROCESSES IN THE SPERM OF THE BOAR AT THE ADD OF METAL NANOSUCCINATES TO THE ECOSPERM MEDIUM}

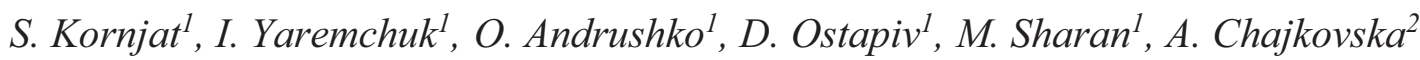 \\ ${ }^{1}$ Institute of Animal Biology of NAAS, \\ 38, V. Stusa str., Lviv, 79034, Ukraine
}

${ }^{2}$ State Scientific Research Control Institute of Veterinary Medicinal Products and Feed Additives, 11, Donetska str., Lviv, 79019, Ukraine

\section{S U M M A R Y}

The purpose of this study was to investigate the effect of complexes of biologically active substances with nanosites in the form of nanosuccinate of manganese, copper and zinc in the diluent 
for the dilution of boar sperm "Ecosperm" on the quality of sperm during storage. It has been established that the addition of trace elements nanosuccinates to the diluent ejaculates affects the intensity of the oxidative processes in the semen, the survival and the activity of the enzyme marker fertilizing ability of the sperm succinate dehydrogenase. Respiratory activity of boars' sperm by the addition of trace elements in the form of a nanocompound with succinate changes ambiguously, and depends on the dose in the diluent and the role of the individual trace element in the sperm exchange processes.

The difference between the control and the maximum dose of $\mathrm{Zn}^{2+}$ succinate is $31.5 \%$, and the effect of the increasing content of the complex compound in the sparse sperm on the respiratory activity of medium force $(\eta=0.410)$. The effect of the increasing content of $\mathrm{Cu}^{2+}-$ and $\mathrm{Mn}^{2+}-$ succinate in sparse boar sperm on the respiratory activity of medium-strength sperm (respectively, $\eta$ $=0.628$ and 0.539$)$. Using the addition of $0.01 \mathrm{ml} / \mathrm{ml}$ succinate $\mathrm{Zn}^{2+}(0,6 \mathrm{mg} / \mathrm{l}), \mathrm{Mn}^{2+}(0,1 \mathrm{mg} / \mathrm{l})-$ and $\mathrm{Cu}^{2+}-(0,04 \mathrm{mg} / \mathrm{l})$ in sparse sperm, the highest survival time of boar sperm was obtained compared to the control and the difference was 33.2, 9.2 and 28.4 hours for zinc, manganese and copper respectively.

The optimal concentrations that ensure the normalization of oxidation processes and high

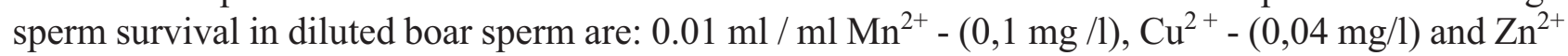
- $(0,6 \mathrm{mg} / \mathrm{l})$ nanosuccinate. Increasing the concentrations of trace elements nanosuccinate in the diluent of more optimal values inhibits the respiratory activity of the sperm, and reduces the activity of succinate dehydrogenase.

Keywords: SPERM, BOAR, DILUENT, SURVIVAL, NANOSUCCINATE, COPPER, MANGAN, ZINC.

\title{
ИНТЕНСИВНОСТЬ ОКИСЛИТЕЛЬНЫХ ПРОЦЕССОВ В СПЕРМЕ ХРЯКОВ ПРИ ДОБАВЛЕНИИ НАНОСУКЦИНАТОВ МЕТАЛЛОВ В РАЗБАВИТЕЛЬ «ЭКОСПЕРМ»
}

\author{
С. Б. Корнят ${ }^{1}$, И. М. Яремчук ${ }^{1}$ О. Б. Андрушко, Д. Д. Остапив ${ }^{1}$ \\ М. М. Шаран ${ }^{1}$, А. И. Чайковская ${ }^{2}$ \\ ${ }^{1}$ Институт биологии животных НААН \\ ул. В. Стуса, 38, г. Львов, 79034, Украина
}

${ }^{2}$ Государственный научно-исследовательский контрольный институт ветеринарных препаратов и кормовых добавок

ул. Донецкая, 11, г. Львов, 79019, Украина

\section{А Н Н О Т А ЦИ Я}

Целью данной работы было изучить влияние комплексов биологически активных веществ в виде наносукцинатов марганца, меди и цинка в составе среды для разбавления спермиев хряков «Экосперм» на качество спермы при хранении. Установлено, что добавление в разбавитель эякулятов хряков наносукцинатов микроэлементов влияет на интенсивность окислительных процессов в сперме, выживание и активность энзима-маркера оплодотворяющей способности спермиев сукцинатдегидрогеназы. Оптимальными концентрациями, которые обеспечивают нормализацию окислительных процессов и высокое выживание сперматозоидов в разреженной сперме хряков являются 0,01 мл/мл среды $\mathrm{Mn}^{2+}$ $\left(0,01 \mathrm{мг/л)}, \mathrm{Cu}^{2+}-\left(0,04\right.\right.$ мг/л) и $\mathrm{Zn}^{2+}(0,6$ мг/л) -наносукцинатов. Увеличение концентраций наносукцинатов микроэлементов в разбавителе больше оптимальных величин ингибирует дыхательную активность спермы и снижает активность сукцинатдегидрогеназы.

Ключевые слова: СПЕРМА, ХРЯК, СРЕДА, ВЫЖИВАНИЕ, НАНОСУКЦИНАТ, МЕДЬ, МАРГАНЕЦ, ЦИНК. 
1. Яблонський $B$. A. Біотехнологічні і молекулярно-генетичні основи відтворення тварин // В. А. Яблонський, С. П. Хомин, В. І. Завірюха та ін. - Львів: Афіша, 2009. - 217 с.

2. Eghbali M. Effects of copper and superoxide dismutase content of seminal plasma on buffalo semen characteristics. / Eghbali M., Alavi-Shoushtari S. M., Rezaii S. A. // Pak. J. Biol. Sci. - 2008. - V. 11. - P. 1964-1968.

3. Лукъянова Л. Д. Кислородзависимые процессы в клетке и ее функциональное состояние / Л. Д. Лукъянова, Б. С. Балмуханов, Л. Т. Уголев. - М.: Наука, 1982. - 262 с.

4. Інтенсивність окисно-відновних процесів та виживання сперміїв кнурів за додавання в розріджені еякуляти наносукцинатів мікроелементів / Корнят С. Б., Андрушко О. Б., Кузьміна Н. В. та ін. // Проблеми зооінженерії та ветеринарної медицини,Збірник наукових праць ХДЗВА,- 2017. - Вип. 34, ч.2. - С. 70-74.

5. Штольц К. Ф. Амперометрическое определение ферроцианида в присутствии субклеточных структур / К. Ф. Штольц, И. М. Мосолова, Л. А. Дронова // Биохимические методы. - М.: Наука, 1980. — С. 147 - 150.

6. Чухрій Б. М. До методики визначення активності окислювальних ферментів у спермі бугаїв / Б. М. Чухрій, Л. О. Клевець // Розведення та штучне осіменіння великої рогатої худоби. - Київ, 1978. - Вип. 10. - С. 42-45.

7. Плохинский Н. А. Руководство по биометрии для зоотехников. - М.: Колос, 1969. $-255 \mathrm{c}$.

\section{References}

1. Jablonskyj V.A. Biotehnolohichni i molekularno-henetychni osnovy vidtvorenna tvaryn // V. A. Jablonskyj, S. P. Homyn, V. I. Zaviruha, M. V. Demchuk ta in. - Lviv: Afisha, 2009. - 217 s. (in Ukrainian).

2. Eghbali M. Effects of copper and superoxide dismutase content of seminal plasma on buffalo semen characteristics. / Eghbali M., Alavi-Shoushtari S.M., Rezaii S.A. // Pak. J. Biol. Sci. - 2008. - V. 11. - P. 1964-1968.

3. Lukjanova L. D. Kislorodzavisimyje processy v kletke i ejo funkcionalnoe sostojanije / L.D. Lukjanova, B. S. Balmuhanov, L. T. Ugolev. — M.: Nauka, 1982. — 262 s. (in Russian).

4. Kornyat S. B., Andrushko O. B., Kuzmina N. V., Bodnar J. V., Sharan M. M., Ostapiv D. D. Intensyvnist okysno-vidnovnyh procesiv ta vyzyvannja spermijiv knyriv za dodavannja v rozridzeni ejakulaty nanosukcynativ mikroelementiv. Problemy zooinzenerii ta veterynarhoji medycyny, Zbirnyk naukovyh prac HDZVA,- Vyp.34, ch.2.- s. 70-74.- 2017. (in Ukrainian).

5. Shtolc K. F. Amperiometricheskoe opredelenie ferrocianida v prisutstvii subkletochnyh struktur / K. F. Shtolc, I. M. Mosolova, L. A. Dronova. Biohimicheskije metody. - M.: Nauka, 1980. - S. 147 - 150. (in Russian).

6. Chuhrij B. M. Do metodyky vyznachennja aktyvnosti okysluvalnyh fermentiv u spermi buhajiv / B. M. Chuhrij, L. O. Klevec // Rozvedennja ta shtuchne osimeninnja velykoji rohatoji hudoby. - Kyjiv, 1978. - Vyp. 10. - S. 42-45. (in Ukrainian).

7. Plohinskij N. A. Rukovodstvo po biometriji dla zootehnicov. - M.: Kolos, 1969. - 255 s. (in Russian).

Рецензент - I. М. Кушнір, д. вет. н., ДНДКІ ветпрепаратів та кормових добавок. 